Maria Komariah : Training dan Coaching pada Pasien Kanker Payudara

\title{
Training dan Coaching pada Pasien Kanker Payudara untuk Meningkatkan Ketaatan Melakukan Praktek Keagamaan
}

\author{
Maria Komariah, Kusman Ibrahim \\ Fakultas Keperawatan, Universitas Padjadjaran \\ Email: maria.komariah@gmail.com
}

\begin{abstract}
Abstrak
Agama dan spiritualitas memegang peranan penting sebagai coping bagi pasien dengan kanker. Hal ini dapat memberikan kenyamanan, harapan dan sesuatu yang berarti bagi mereka. Praktik keagamaan sebagai spirtualitas yang dapat membantu seseorang dalam menentukan hubungannya dengan alam semesta. Spiritualitas mulai dikenal luas sebagai salah satu elemen yang penting dalam dunia kesehatan, hal ini menunjukkan bahwa spiritualitas telah menjadi perhatian berbagai profesi kesehatan. Beberapa penelitian menjelaskan mengenai efek dari spiritualitas sebagai sumber yang kuat untuk beradaptasi dengan masalah yang berhubungan dengan kesehatan, terutama pada pengelolaan pasien dengan penyakit kronik atau terminal, salah satunya kanker, dikarenakan populasi ini sangat rentan terhadap masalah fisik, psikologis dan spiritual terkait penyakit dan efek samping dari pengobatannya. Beberapa kajian juga mengungkapkan bahwa praktik keagamaan sebagai sumber dukungan yang penting bagi pasien. Tujuan dilakukannya pengabdian masyarakat ini adalah untuk meningkatkan ketaatan dalam melakukan praktik keagamaan pada pasien kanker payudara yang sedang menjalani kemoterapi. Materi yang disampaikan meliputi: apa itu kanker payudara, penyebab dan faktor risiko, penatalaksanaan dan efek samping, pengelolaan gejala, bagaimana salat dan zikir bermanfaat untuk pasien kanker payudara, bagaimana melakukan salat dan zikir untuk mendapatkan manfaat terbaik. Pelaksanaan kegiatan menggunakan metode sharing, training dan coaching. Hasil menunjukkan adanya peningkatan ketaatan dalam melakukan praktik keagamaan setelah mengikuti program (88.53\%) dibandingkan dengan sebelum menerima program $(72,16 \%)$, beberapa partisipan juga mengungkapkan perasaan tenang dan damai setelah mengikuti program. Pemberian training dan coaching ini terbukti dapat meningkatkan ketaatan dalam melakukan praktik keagamaan.
\end{abstract}

Kata kunci: Kanker payudara, praktik keagamaan, training.

\begin{abstract}
Religion and spirituality play a central role in patient's coping with cancer, and providing comfort, hope, and meaning to them. Religious practices as spirituality, which may assist people in determining relationship with the universe. Spirituality is widely known as one of the important elements of health, it shows that spirituality has become the concern of various health professions. Several studies explained the effects of spirituality as a powerful source for adapting to health-related problems, especially in the management of patients with chronic or terminal illness, such as cancer, since this population is very vulnerable to physical, psychological and spiritual problems related to the disease and the side effects of its treatment. Some studies have revealed that religious practice is an important support for patients. The purpose of community service is to increase the compliance on religious practices in breast cancer patients undergoing chemotherapy The health education material presented includes: what is breast cancer, causes and risk factors, management and side effects, management of symptoms, how prayers and dhikr are beneficial for breast cancer patients, how to perform prayers and dhikr to get the best benefits. Implementation of activities using the method of sharing, training, and coaching. The results show that there was increased in compliance on conducting religious practices before receiving the program (72.16\%) compared to after receiving the program (88.53\%), some participants also stated that they feel calm and peace after participating the program. Training and coaching could improve the compliance on religious practices in breast cancer undergoing chemotherapy.
\end{abstract}

Keywords: Breast cancer, religious practices, training.

MKK: Volume 2 No 2 November 2019 


\section{Pendahuluan}

Agama dan spiritualitas memegang peranan penting sebagai coping bagi pasien dengan kanker. Hal ini dikarenakan dapat memberikan kenyamanan, harapan dan sesuatu yang berarti bagi mereka. Praktik keagamaan sebagai spirtualitas yang mana dapat membantu seseorang dalam menentukan hubungannya dengan alam semesta. Spiritualitas mulai dikenal luas sebagai salah satu elemen yang penting dalam dunia kesehatan (Puchalski, 2010), hal ni menunjukkan bahwa spiritualitas telah mulai menjadi perhatian berbagai profesi kesehatan. Beberapa penelitian menjelaskan mengenai efek dari spiritualitas sebagai sumber yang kuat untuk beradaptasi dengan masalah yang berhubungan dengan kesehatan, terutama pada pengelolaan pasien dengan penyakit kronik atau terminal. Kegagalan beradaptasi pada fase denial dan anger saat didiagnosa mengalami penyakit kronis dapat menyebabkan penurunan aspek spiritualitas dalam bentuk penurunan aktivitas ibadah (Antoni et al., 2009). Selain itu, Narayasanamy (2009) mengungkapkan bahwa praktik keagamaan sebagai sumber dukungan yang penting bagi pasien.

Salah satu aspek perilaku dari spiritualitas adalah dengan melibatkan cara seseorang melakukan sesuatu yang terlihat secara kasat mata (praktik keagamaan) yang merupakan manifestasi dari keyakinan spiritual seseorang dan kondisi spiritual dalam diri orang tersebut (Anandarajah \& Hight, 2001). Study yang dilakukan oleh Levin, Larson, and Puchalski (1997) melaporkan bahwa keyakinan terhadap suatu agama sangat membantu seseorang dalam mencegah penyakit (termasuk kondisi depresi, dan penyakit fisik lainnya), membantu dalam beradaptasi dengan kondis sakit yang dialami dan dapat membantu beradaptasi pada saat fase pemulihan dari sebuah penyakit.

Banyak praktik keagamaan menggunakan doa, kata-kata atau aktifitas fisik yang diyakini dapat memberikan ketenangan dan situasi relaks. Beberapa penelitian telah dilaporkan bahwa praktik meditasi dapat meningkatkan efek relaksasi dan meningkatkan efek kesehatan. Relaksasi tersebut didapatkan dari dua prosedur sederhana yaitu mengulang sebuah kata, frase atau aktivitas otot dan menghilangkan pikiran yang mengganggu dalam pikiran. Menurut Benson (1996) kedua aktivitas tersebut bila dilakukan secara teratur, dapat menimbulkan efek fisiologis dan psikologis yang baik 
sehingga dapat dijadikan terapi untuk beberapa kondisi medis. Dalam masyarakat Muslim aktivitas tersebut dikenal dengan aktivitas zikir dan salat.

Kemoterapi berdampak terhadap penurunan kondisi fisik, psikologis, dan hubungan interpersonal, namun kemoterapi menyebabkan ketidakberdayaan sehingga seseorang akan cenderung meningkatkan spiritual keagamaan. Penelitian telah banyak mengungkapkan bahwa seseorang yang hidup dengan penyakit kronik, seperti kanker, menjadi sensitive dan terjadi peningkatan kesadarannya terhadap rasa spiritualitas dan kebutuhan akan pemenuhan spiritualitas itu sendiri (Taylor, 2009). Pemenuhan kebutuhan spiritual dapat dijadikan suatu terapi alternatif atau terapi komplementer dengan membantu pasien untuk beradaptasi lebih baik terhadap aspek fisik maupun psikologis akibat penyakit atau efek samping dari pengobatan, i.e, kemoterapi. Namun kenyataan di tatanan klinis menunjukkan bahwa aspek spiritual dalam pemberian pelayanan kesehatan belum mendapatkan perhatian yang adekuat dan penerapannya masih jarang (MacDonald, 2001; Manning-Walsh, 2005). Selain itu, petugas kesehatan lebih percaya diri untuk melakukan pemenuhan perawatan dari aspek fisik dibandingan aspek spiritual (Kliwer, 2004; Prasetyo, 2016).

Berdasakan beberapa hasil studi dilaporkan bahwa kebanyakan pasien kanker payudara menggunakan keagamaan untuk membantu coping mereka terhadap kanker. Yang paling sering digunakan sebagai terapi alternative adalah salat, zikir meditasi, dan pengobatan spiritual lainnya (Wancai, Amer, \& Stewart, 2010). Hasil penelitian ini juga konsisten dengan hasil temuan sebelumnya terhadap pasien Muslim dengan kanker payudara yang menyatakan bahwa kebanyakan pasien melakukan praktik-praktik keagamaan selama mereka berjuang melawan kanker (Can, Demir, \& Aydirez, 2012).

Oleh karena itu, penulis mencoba untuk memberikan suatu program berupa training dan coaching tentang bagaimana cara melakukan salat dan zikr yang benar sehingga dapat memberikan manfaat yang optimal bagi pasien kanker payudara yang sedang menjalani kemoterapi, dan juga sebagai upaya pemenuhan kebutuhan spiritual. Pada makalah ini penulis akan melihat aspek spiritualitas dilihat pada ketaatan pasien 
dalam menjalankan praktik keagamaan (salat 5 waktu dan zikir setelah salat) sebelum dan sesudah mendapatkan program pendidikan kesehatan.

\section{Metode}

Program pengabdian masyarakat dilaksanakan di Klinik Kemoterapi, Bandung, Jawa Barat. Sasaran dari program ini adalah seluruh pasien Muslim dengan kanker payudara yang sedang menjalani kemoterapi siklus 1-4, karena mereka biasanya sering mengalami keluhan seperti mual, muntah, kelelahan, tidak bisa tidur, keputusasaan, kecemasan akibat penyakit dan efek samping dari pengobatan yang diterimanya.

Metode pelaksanaan pada program penyuluhan masyarakat ini dilaksanakan secara sistematis, sebagai berikut: 1) Pemilihan klinik kemoterapi sebagai sasaran; 2) survey klinik sasaran; 3) Observasi lapangan; 4) Penyusunan materi training; 5) Rencana kegiatan; 6) Izin pelaksanaan; 7) Sosialisasi program; 8) Pelaksanaan program kegiatan; 9) Pembuatan Laporan akhir.

1. Pemilihan klinik kemoterapi sebagai sasaran yang akan digunakan untuk melakukan kegiatan sosialisasi. Tim berdiskusi untuk menentukan klinik yang tepat sesuai sasaran dilihat dari jumlah kunjungan pasien yang datang setiap harinya. Juga menentukan topik penelitian dan pendidikan kesehatan yang sesuai dengan kondisi masalah pasien.

2. Survey klinik sasaran

Tim berdiskusi dan menentukan klinik sasaran setelah mendapatkan informasi mengenai kondisi pasien di klinik kemoterapi.

3. Observasi lapangan

Dengan melakukan survey lapangan, observasi, dan wawancara dengan beberapa pasien yang sedang menjalani kemoterapi. Informasi yang didapat bahwa pasien kebanyakan mengalami kecemasan, putus asa, bingung dengan kondisi penyakitnya, berusaha menerima kondisi penyakitnya dengan lebih banyak beribadah. Dari hasil wawancara juga diperoleh informasi bahwa mereka membutuhkan pemenuhan aspek 
spiritual dari tenaga kesehatan untuk mengatasi masalah fisik dan psikologis yang dialami akibat penyakit kanker dan perawatannya.

4. Penyusunan materi training

Materi training didiskusikan dalam Tim, dan disusun rancangannya.

5. Rencana kegiatan

Menyusun jadwal pendidikan kesehatan meliputi waktu yang tepat, perijinan rumah sakit, perijinan ruangan dengan melakukan pendekatan dan pemberian informasi mengenai maksud dan tujuan kegiatan.

6. Izin pelaksanaan

Tim membuat ijin dari Fakultas Keperawatan dan rumah sakit yang memiliki Klinik Kemoterapi di Bandung.

7. Sosialisasi program

Tim melakukan sosialisasi program dengan menjelaskan tentang rencana pendidikan kesehatan di ruang klinik kemoterapi.

8. Pelaksanaan program kegiatan

Setelah semua keperluan disiapkan, tim mulai melakukan pendekatan ke pasien dengan mendatangi satu persatu pasien agar ikut terlibat dalam kegiatan pendidikan kesehatan selama menjalani kemoterapi. Pada sesi ini pula setiap peserta mendapakan booklet berisi materi penyuluhan, handsfree, dan MP3 sebagai panduan melakukan zikir. Adapun materi pendidikan kesehatan terdiri dari: 1) apa itu kanker payudara; 2) penyebab dan faktor risiko; 3) Penatalaksanaan dan efek samping; 4) pengelolaan gejala; 5) bagaimana salat dan zikir bermanfaat untuk pasien kanker payudara; 6) bagaimana melakukan salat dan zikir untuk mendapatkan manfaat terbaik; 7) doa bersama.

Materi-materi tersebut disampaikan bersifat sharing, diikuti oleh praktek salat dan zikir selama 30 menit. Setelah itu pasien diminta untuk mengekspresikan perasaannya setelah melakukan salat dan zikir dengan benar.

Program dilaksanakan pada periode April - Juni 2019.

9. Pembuatan laporan akhir 


\section{Hasil}

Menurut data yang diperoleh dari statistik di klinik kemoterapi, jumlah pasien kanker payudara yang menjalani kemoterapi di bangsal ini adalah sekitar 211 per bulan. Sedangkan, kapasitas tempat tidur adalah 35. Jumlah total pasien dengan semua jenis kanker yang menjalani kemoterapi adalah sekitar 30-38 pasien per hari dan sekitar 94\% pasien yang datang beragama Islam. Mereka menjalani kemoterapi setiap 2, 3, atau 4 minggu sekali sesuai dengan jenis obat yang diterima. Tidak ada program pendidikan atau kegiatan khusus lainnya yang diberikan kepada pasien secara teratur, sehingga pemberian informasi seputar kanker payudara berikut manfaat dari praktik keagamaan dalam agama Islam dirasa perlu untuk membantu kondisi fisik, psikologis dan spiritual pasien.

Jumlah total pasien yang berpartisipasi dalam kegiatan pendidikan kesehatan sebanyak 53 orang, dan dipilih yang menjalani kemoterapi setiap 3 minggu. Berdasarkan hasil dari pengkajian awal ketaatan terhadap praktik keagamaan pasien kanker payudara, dalam hal ini keteraturan menjalankan salat 5 waktu dan zikir setelah salat, didapatkan data 72,16\% mereka melakukan salat dan zikir dengan teratur. Hal ini disebabkan mereka sangat menderita dengan efek samping yang ditimbulkan setelah menerima kemoterapi, seperti perasaan mual, kelelahan yang sangat, stomatitis, konstipasi dan lain-lain, walau pun begitu mereka tetap berusaha untuk melakukan salat dan zikir karena sudah menjadi kewajiban sebagai umat Muslim sesuai kemampuan mereka.

Setelah didapatkan data awal, kegiatan dilanjutkan dengan pemberian materi pendidikan kesehatan seputar penyakit kanker payudara, seperti stadium, penyebab dan faktor risiko, perawatan dan efek sampingnya, pengelolaan gejala, dilanjutkan dengan penjelasan tentang bagaiman salat dan zikir bermanfaat bagi pasien kanker payudara. Pemberian materi ini menggunakan media booklet dan disampaikan dengan cara sharing dengan maksud tidak menggurui pasien. Setelah pemberian materi pendidikan kesehatan tentang kanker payudara selesai, sesi selanjutnya adalah diskusi tentang salat dan zikir serta manfaatnya terhadap kesehatan. Diawali dengan sharing pengalaman dalam melaksanakan salat dan zikir selama ini dari setiap peserta, dilanjutkan dengan simulasi 
dan coaching bagaimana mengerjakan salat dengan baik dan benar, diikuti dengan praktik zikir selama 30 menit. Setelah praktik zikir selesai, peserta diminta merefleksikan perasaan setelah melakukan praktek salat dan zikir dengan benar. Setelah selesai pasien diminta untuk melakukan salat dan zikir seperti yang sudah diajarkan di rumah masingmasing, dan diminta untuk melaporkan kegiatan tersebut berikut mencatat perasaanperasaan yang muncul di formulir aktivitas harian yang sudah disediakan, formulir tersebut memuat informasi tentang aktivitas salat 5 waktu, zikir setelah salat, dan perasaan-perasaan yang muncul setelah melakukan salat dan zikir, kemudian dikumpulkan saat kemoterapi selanjutnya.

Pertemuan selanjutnya setelah 3 minggu. Setiap partisipan dicek formulir aktivitas harian selama 21 hari, dan didapatkan data tentang ketaatan mereka terhadap praktik keagamaan menjadi 88,53\%. Beberapa partisipan juga mengekspresikan perasaannya seperti, merasa lebih tenang, optimis terhadap masa depan, dan pasrah kepada kehendak Allah.

\section{Pembahasan}

Berdasarkan hasil temuan pada program pengabdian masyarakat ini dilaporkan bahwa terjadi peningkatan ketaatan dalam menjalankan kegiatan keagamaan, salat dan zikir, pada pasien kanker payudara sesudah diberikan training dan coaching tentang manfaat salat dan zikir bagi mereka yang sedang menjalani kemoterapi.

Pemenuhan kebutuhan spiritual sangat dibutuhkan oleh pasien kanker yang sedang menjalani kemoterapi, karena hal ini dapat menjadi kunci strategi koping bagi pasien dalam menghadapi berbagai macam tekanan yang berhubungan dengan ancaman akibat sakit, penyakit kronis, dan efek samping dari penyakit dan pengobatannya (Laubmeier, Zakowski, Bair, 2004; Prasetyo, 2016).

Selain itu, menurut Kliwer (2004) dilaporkan bahwa semakin baik kondisi spiritual seseorang maka hal tersebut dapat sebagai pengobatan paling awal bagi individu. Beberapa pasien telah membuktikan bahwa kondisi spiritual mereka dapat memberikan 
dukungan yang diperlukan dalam menghadapi krisis akibat penyakit, baik secara fisik ataupun psikis (Meraviglia, 2006).

Penelitian sebelumnya juga melaporkan bahwa mayoritas partisapan menceritakan bahwa kualitas spiritual yang berkaitan dengan keimanan dan pendekatan diri pada Tuhan selama kemoterapi mengalami peningkatan (Ruhyanudin, Waluyo \& Yulia, 2018).

Dengan melibatkan dukungan spiritual keagamaan dan keunikan karakter masingmasing individu dipadukan dengan kompleksnya permasalahan yang dialami oleh pasien kanker payudara yang sedang menjalani kemoterapi menyebabkan reaksi atau respon yang berbeda. Ketika seseorang dalam kondisi tidak berdaya maka sering muncul spirit keagamaan. Pada Masyarakat Islam, mereka berkeyakinan bahwa "manusia hanya berusaha tetapi Tuhanlah yang menentukan". Hal tersebut menimbulkan keyakinan bahwa manusia tidak mempunyai kemampuan untuk menentukan dirinya sendiri, tetapi semua terjadi adalah karena kehendak-Nya. Sehingga tidak ada jalan lain kecuali dengan mendekatkan diri pada-Nya. Pada saat mengalami situasi ketidakberdayaan dan ketidaknyamanan, individu akan mencari dukungan dari keyakinan agamanya. Dukungan ini sangat diperlukan untuk dapat menerima keadaan sakit, khususnya jika penyakit tersebut memerlukan proses penyembuhan yang lama dan dengan hasil yang belum pasti. Melakukan aktivtas salat, zikir, berdoa, dan membaca kitab suci dan juga praktek keagamaan lainnya sering membantu memenuhi spiritual yang juga merupakan suatu perlindungan terhadap terhadap tubuh (Hamid, 2000; Ruhmayudin et al., 2018).

Menurut Sufi, inti dari praktik keagamaan dalam Islam adalah salat dan zikir (meditasi) (Appel \& Kim-Appel, 2009). Praktik-praktik keagamaan dalam Islam ini mempunyai peranan penting dalam proses penyembuhan dan pemulihan suatu penyakit (Yucel \& Nursi, 2010).

Salat bukan hanya kewajiban agama umat Islam tetapi juga memiliki kekuatan atau energy spiritual yang dapat meningkatkan kehidupan kita sehari-hari secara ajaib. Jika seseorang sudah melakukan salat setiap hari, maka sudah pasti mulai merasakan manfaat dari salat, seperti, salat menahan tubuh kita dari banyak penyakit seperti penyakit 
mental, gangguan kecemasan, kelelahan, penyakit saraf, dan lain-lain, karena salat membuat pikiran tenang. Selain itu, ketika kita melakukan salat, olahraga juga dilakukan bersamaan, yang meningkatkan aliran darah ke tubuh, memberikan energi, meningkatkan kebugaran tubuh dan meningkatkan kekebalan penyakit. Selain itu, dengan melakukan salat dengan teratur membantu kita berjalan di jalan yang benar dan juga meningkatkan hubungan yang kuat dengan Sang Pencipta (Allah), sehingga dapat meningkatkan kondisi spiritual, penyucian jiwa dengan terus-menerus mengingat Allah, cara untuk mengungkapkan rasa terima kasih kepada Allah dan mendapatkan rahmat dan pengampunan dari Allah. Hal-hal tersebut sangat diperlukan untuk mendukung mental para pasien kaker yang sedang menjalani kemoterapi.

Manfaat melakukan salat yang lainnya adalah, salat merupakan bentuk latihan ringan. Ini melibatkan pergerakan semua bagian tubuh dan beberapa gerakan tidak biasa yang biasanya tidak kita lakukan selama rutinitas harian. Namun, salat tidak cukup hanya gerakan, tetapi juga harus dilakukan dengan perlahan, diam, serta konsentrasi pikiran yang hanya berfokus pada Allah (Kamran, 2018).

Manfaat kesehatan hanya datang jika tindakan salat dilakukan persis dengan cara yang telah diperintahkan oleh Allah dan Nabi Muhammad (SAW). Pendekatan yang tidak akurat atau tergesa-gesa dapat menyebabkan lebih banyak masalah daripada manfaat (misalnya gerakan ruku yang tidak akurat saat membungkuk dapat merusak tulang punggung) (Minciter Team, 2017).

Selain itu, salat juga membutuhkan konsentrasi penuh, seseorang tidak mampu memikirkan hal lain. Merasakan dilihat Allah, didengarkan Allah, dan diawasi Allah, tidak ada pertemuan yang lebih penting dari ini. Jadi, efek salat yang bermanfaat bagi kesehatan hanya datang dengan praktik salat yang benar dan tepat dengan keteraturan dan konsentrasi (Kamran, 2018).

Selain kegiatan salat juga ada zikir. Zikir banyak diartikan sebagai mengingat Allah. Zikir merupakan bentuk sikap pasif atau pasrah dengan menggunakan kata yang diulang-ulang, sehingga menimbulkan respon relaksasi, yakni perasaan atau 'sensasi' tenang (Purwanto, 2013). 
Ketika seseorang melakukan zikir, respon relaksasi digabungkan dengan keyakinan (keimanan). Pengulangan kata-kata yang dipilih akan dapat membangkitkan kondisi relaks. Metode penggabungan ini lebih efektif bila dibandingkan dengan relaksasi yang tidak melibatkan faktor keimanan (faith factor). Metode 'tingkat relaksasi' ini bisa menghantarkan pada relaksasi yang teramat dalam.

Melalui zikir ini diharapkan dapat membawa subjek pada alam transendental. Alam transendental akan memberikan suatu 'state' yang berbeda (the altered state of consciousness) dimana 'state' kesadaran ini juga akan merubah 'state of mind' dan 'state of emotion'.

Pada keadaan ini, bila dilanjutkan dengan sikap pasrah, maka akan menimbulkan efek yang sangat luar biasa secara spiritual, karena pendekatan kepada Allah tidak dapat dilakukan kecuali dengan menyerahkan diri secara total kepada Allah.

Pasrah dapat dideskripsikan sebagai sebuah sikap penyerahan total kepada objek transenden, yaitu Allah SWT. Dengan sikap ini, apapun yang terjadi dalam diri diterima tanpa reserve, sehingga sangat efektif untuk menimbulkan sikap pasif. Untuk dapat melakukan relaksasi zikir dengan baik yang bisa memberikan efek ketenangan dan terhindar dari beban pikiran karena stress yang berlebihan (Purwanto, 2013).

Pada intinya, relaksasi zikir menuntut kita untuk bisa masuk dalam 'state of mind' kepasrahan kepada Sang Pencipta. Karena, begitu kita merasakan sikap pasrah, kita akan sadar sepenuhnya kepada Allah. Semakin kita bisa merasa pasrah dan ikhlas menerima penyakit yang kita alami, maka seluruh anggota badan pun akan menerimanya dan akan merasakan ikhlas. Pada keadaan ini, pada akhirnya terciptalah perasaan relaks dan santai yang hingga pada akhirnya menemukan ketenangan pikiran. Hal ini sesuai dengan ungkapan beberapa partisipan bahwa setelah mengikuti program mereka merasakan kedamaian dan ketenangan.

Pada makalah ini penulis tidak menjelaskan dampak fisik dan psikologis dari partisipan. Pada kegiatan pengabdian pada masyarakat selanjutnya diharapkan aspekaspek tersebut dapat dijelaskan dan terukur dengan baik. 


\section{Simpulan}

Saat ini, spiritualitas dapat menjadi bagian penting dari hidup dikaitkan dengan diagnosis penyakit kronik seperti kanker, karena dapat membawa perasaan damai. Kualitas keimanan bersama dengan kekuatan agama, seperti salat dan zikir, memiliki peran penting dalam penerimaan penyakit, sehingga dapat mengurangi depresi dan penyakit mental dan meningkatkan kondisi fisik-psikologis.

Dengan program pengabdian masyarakat ini jelas terlihat adanya peningkatan ketaatan dalam melakukan praktik keagamaan yaitu salat dan zikir, hal ini diharapkan akan berdampak pada kondisi kesehatan mental dan spiritual mereka.

\section{Ucapan Terimakasih}

Kegiatan Pengabdian pada Masyarakat ini dapat terselenggara karena kerja sama yang baik dan dukungan dari Tim Fakultas Keperawatan dan juga teman-teman perawat di Klinik Kemoterapi rumah sakit di Bandung.

\section{Daftar Pustaka}

Anandarajah, G., \& Hight, E., (2001). Spirituality and medical practice: Using the HOPE questions as a practical tool for spiritual assessment. American Family Physician, $63,81-9$.

Appel, J., \& Kim-Appel, D. (2009). Mindfulness: Implications for substance abuse and addiction. International Journal of Mental Health and Addiction, 7(4), 506. doi:10.1007/s11469-009-9199-z

Benson H. (1996) Timeless healing: The power and biology of belief. New York: Scribner.

Gulbeyaz, Can., Melike, Demir., Adnan, Aydirez. (2012). Complementary and alternative therapies used by Turkish breast cancer patients undergoing chemotherapy. Breast Cancer, 7, 471-475.

Hamid, A.Y. (2010). Buku ajar aspek spiritual dalam keperawatan. Jakarta: Widya Medika.

Kamran, G. (2018). Physical benefits of (salah) prayer-strengthen the faith and 
Fitness. Journal of Novel Physiotherapy and Rehabilitation, 2, 43-53.

Kliewer S. (2004) Allowing spirituality into the healing process. Journal of Family Practice, 53(8), 616- 624.

Laubmeier KK, Zakowski SG, Bair JP. (2004) The role of spirituality in the psychological adjustment to cancer: a test of the transactional model of stress and coping. International Journal Behavor Medicine, 11(1), 48-55.

Levin, J.S., Larson, D.B., Puchalski, C.M,. (1997) Religion and spirituality in medicine: research and education. JAMA, 278, 792-3.

Macdonald BH (2001) Quality of life in cancer care: patients' experiences and nurses' contribution. European Journal Oncology Nursing, 5(1): 32- 41.

Manning-Walsh JK (2005). Psychospiritual well-being and symptom distress in women with breast cancer. Oncology Nursing Forum, 32(3), 537-543.

Minciter Team. (2017). Know the Benefits of 5 Times Prayer (Salah) in a Day. Retrieved from: http://www.minciter.com/2017/06/know-benefits-of-5-timesprayer-salah.html.

Meraviglia, M. (2006). Effects of spirituality in breast cancer survivors. Oncology Nursing Forum, 33, (1).

Prasetyo, A. (2016). Aspek spiritualitas sebagai elemen penting dalam kesehatan. Jurnal Kesehatan Al-Irsyad, 18-24.

Puchalski CM (2010) Formal and Informal Spiritual Assessment. Asian Pacific Journal Cancer Prevention, 11, MECC Supplement, 51- 57.

Purwanto, S. (2013). Dzikir Nafas [Breath Dzikr]. Surakarta, Central Java: Cendana Ofset.

Ruhyanudin, F,. Waluyo, A., Yulia. (2018). Pengalaman pasien kanker dalam menjalani kemoterapi: Studi fenomenologi di RPAD Gatot Soebroto Ditkesad Jakarta. Research Report. 101-110.

Taylor EJ (2009) Caring for the spirit. in: burke cc, ed. Psychosocial Dimensions of Oncology Nursing Care. 2nd ed. Pittsburgh: oncology nursing society; 2009: 5974.

Wanchai, Ausanee, Armer., Stewart. (2010). Complementary and alternative medicine use among women with breast cancer: A systematic revew. Clinical Journal of 
Maria Komariah : Training dan Coaching pada Pasien Kanker Payudara

Oncology Nursing, 14(4), 45-55.

Yucel, S., \& Nursi, S. (2010). Prayer and Healing in Islam With Addendum of 24 Remedies for the Sick by Said Nursi. Retrieved from

https://www.academia.edu/6183653/Prayer_and_Healing_in_Islam. 